\title{
Process optimization for producing cowpea added instant kheer mix using response surface methodology
}

\begin{abstract}
Kheer is a cereal based dessert commonly prepared using rice or any other staple cereal, milk and sugar, popular in India and South East Asian countries. In the present endeavour, a modified instant kheer mix was devised wherein cowpea and malted wheat flour were added along with rice, skim milk powder and sugar. These additions were done to enhance the nutritional properties of kheer. Response surface methodology (RSM) and central composite design (CCD) were used in optimization of instant kheer mix. The objective was to devise the best combination of process variables, so as to obtain optimal recipe having high protein as well as overall acceptability. Variants of instant kheer mixes were tried and tested for acceptability using varying amounts of different ingredients. Best variant was selected by a semi trained panel using 9 point hedonic test and taken up for optimization. Process variables were amounts of cowpea, cowpea soaking time and amount of malted wheat flour and responses were protein, crude fiber and overall acceptability. Regression models and response surface plots were generated and adequacy was tested with regression coefficients $\left(\mathrm{R}^{2}\right)$ and the lack of fit tests. The best recipe of highest desirability was chosen and its organoleptic attributes were evaluated using 5 point composite rating scale. Nutritional analysis of the optimum recipe was done. Results of ANOVA indicated that process variables had a significant effect on the response; protein $(\mathrm{p}<0.05)$. Results for regression coefficients suggested a fair fit of the model. The optimum instant kheer mix had $12 \mathrm{~g}$ cowpea, with 4hours soaking of time and $5.01 \mathrm{~g}$ malted wheat flour. Its responses were $10.273 \mathrm{~g}$ protein, $0.076 \mathrm{~g}$ crude fiber and 8.052 overall acceptability liked highly). The optimized recipe was high in protein and had good sensory characteristics.
\end{abstract}

Keywords: cowpea, kheer mix, process optimization, response surface methodology
Volume I Issue 5 - 2014

\author{
Khushboo Gupta, Mansi Verma, Payal Jain, \\ Monika Jain \\ Department of Food Science and Nutrition, Banasthali Vidyapith, \\ India \\ Correspondence: Monika Jain, Associate Professor, \\ Department of Food Science and Nutrition, P O: Banasthali \\ Vidyapith-304022, Rajasthan, India, Tel 0988728I046, Fax \\ 01438228587, 01438228365 , \\ Email drmonikajain2000@gmail.com
}

Received: August 14, 2014 | Published: November 12, 2014
Abbreviations: RSM, response surface methodology; ANOVA, analysis of variance; SMP, skimmed milk powder; CCD, central composite design; $\mathrm{R}^{2}$, regression coefficient; $\mathrm{CV}$, coefficient of variation

\section{Introduction}

An estimated 50 to $55 \%$ of milk produced in India is converted into various traditional milk products including numerous dairy desserts. A variety of sweet desserts to suit different festive occasions are manufactured, mainly in unorganized sector across the country. One of the most common traditional dairy desserts is kheer. It is one such product which is offered on religious occasions, social functions and festivals. Kheer has evolved itself to suit regional and personal preferences. ${ }^{1}$ It is a semi solid cereal-based dairy dessert prepared by cooking rice with sugar or jaggery in milk till the point when rice starch gets gelatinized. The major ingredients of kheer are milk, sugar, rice, dry fruits and flavourings. ${ }^{2}$ The essential ingredients are milk and sugar, but recipe of kheer can be varied by replacing rice with vermicelli, semolina, and even carrot. Whole grain cereals or even beaten cereal products are used for kheer making. Consistency of kheer like desserts may vary from almost liquid to viscous semisolid type product. Rice, ${ }^{3}$ makhana ${ }^{4}$ and cracked wheat, i.e, dalia ${ }^{5}$ have been commonly used to make kheer. Apart from rice and dalia, other ingredients, i.e, cowpea or soybean may also be used for kheer making, as these foods contain some specific health promoting factors.
Cowpea and whole wheat have some significant health benefits. In unison they can provide a cereal pulse combination enhancing the protein quality. Traditional kheer is not a rich sources of fiber. Blending of whole wheat flour and cowpea in the recipe could increase the fiber content and enhance nutritional benefits, therefore, rice was substituted by this cereal legume combination. Cowpea (Vigna unguiculata) is grown and consumed all over the world, especially in developing countries like India and China. ${ }^{6}$ It is a famous traditional Chinese herbal medicine, which has functions of nourishing spleen, kidney, curing vomiting and dysentery. ${ }^{7}$ Wheat (Triticum L aestivum) is deemed elite grain and is rightly called the 'king of wild grass'. Wheat is regarded as most important cereal not because of its antiquity but due to being an excellent food for mankind. Consumption of wheat reduces the risk of cardiovascular disease, type II diabetes mellitus, obesity and cancer. ${ }^{8}$ In this study malted wheat flour was used because it is relatively rich source of maltose, mineral, soluble protein, alphaamylase enzyme and flavor substances compared to plain wheat flour. It is inexpensive and can be made easily at home. Several dry mixes based on rice, wheat, oat-based products, have been used in readyto-reconstitute forms, with enhanced shelf life. ${ }^{1-3,9-11}$ Many of these products have become popular due to ease of consumption, increased shelf life and close resemblance to the traditionally consumed dessert prepared at domestic level.

Applications of science and technology within the food system have allowed production of foods in adequate quantities to meet the 
needs of the society as it has evolved. ${ }^{12}$ One of the recent techniques being used for development of optimum food products to enhance their nutritive quality is process optimization. RSM has been used to develop and optimize the processing parameters of several readyto-eat and ready-to-reconstitute products. Attempts have been made earlier in applying RSM for optimizing the ready-to-eat pearl millet kheer dessert for obtaining a product with acceptable quality. ${ }^{2}$ A group of researchers developed ginger based ready-to-eat appetizers using RSM. ${ }^{13}$ Chakraborty et al. ${ }^{14}$ optimized the parameters on textural and overall acceptability of millet enriched biscuits using RSM. Another group of researchers conducted a study to observe the effect of baking conditions on the physical properties of herbal bread using RSM. ${ }^{15}$ No study has yet been reported related to optimization of instant kheer mix with cowpea and malted wheat flour. Therefore, the objective of this study was to formulate protein rich instant kheer mix incorporating cowpea and malted wheat flour and to investigate the optimal combination to yield maximum protein and high acceptability, using RSM.

\section{Materials and methods}

This study was conducted in Banasthali Vidyapith, Rajasthan, India in between July, 2013 to February, 2014. Cowpea, wheat and gingelly seeds were obtained from local market of Shahjahanpur, (Uttar Pradesh). Whey protein concentrate (Mahan Protein Limited, New Delhi: protein $80 \%$, fat $6-8 \%$, minerals 6-7\%), and skimmed milk powder (SMP) (Gopaljee brand, G.K. Dairy and Milk Products Pvt. Ltd., Faridabad, Haryana; energy $365 \mathrm{Kcal}$, protein $36 \mathrm{~g} / 100 \mathrm{~g}$, total carbohydrate $51 \mathrm{~g} / 100 \mathrm{~g}$, fat $0.99 \mathrm{~g} / 100 \mathrm{~g}$ ) were used in the formulation of instant kheer mix. Rice was procured from the local market of Banasthali Vidyapith, Rajasthan. The ingredients used in reconstitution, toned milk ( $3 \%$ fat, Saras), sugar and cardamom powder were obtained from the local market of Banasthali Vidyapith.

\section{Processing of ingredients}

Rice flour and gingelly seed powder were prepared by roasting and grinding of rice grains and gingelly seeds separately. Cowpea was soaked (for different lengths of time), dried at $80^{\circ} \mathrm{C}$ for $10-12$ hours, roasted and then grinded to prepare the flour. In order to prepare malted wheat flour, good quality grains were steeped in cold water for 36 hours at room temperature with two or three changes of water. The germination was allowed to proceed for 3 days at room temperature. After that the whole wheat grains were dried at $80^{\circ} \mathrm{C}$ for 10 -12hours Dried grains were roasted, sprouts of grains were removed and then they were grinded.

\section{Formulation and standardization of food product}

The ingredients included gingelly seed powder, rice flour, skimmed milk powder and whey protein concentrate. Standard recipe was prepared by incorporating roasted and ground gingelly seed powder $(2 \mathrm{~g})$, rice flour $(10 \mathrm{~g})$, SMP $(10 \mathrm{~g})$ and whey protein concentrate $(2 \mathrm{~g})$. Its four variants were prepared by incorporating varying amounts of cowpea powder and malted wheat flour. The cowpea also varied on the time used for soaking. The four variants were: Variant I- $10 \mathrm{~g}$ cowpea with 3 hours soaking $+5 \mathrm{~g}$ malted wheat flour; variant II-3g cowpea with 6 hours soaking $+7 \mathrm{~g}$ malted wheat flour; variant III- $-\mathrm{g}$ cowpea with 9hours soaking $+9 \mathrm{~g}$ malted wheat flour; variant $\mathrm{IV}-5 \mathrm{~g}$ cowpea with 12 hours soaking $10 \mathrm{~g}$ malted wheat flour.

\section{Reconstitution of Instant Kheer Mix into Kheer}

Hundred $\mathrm{ml}$ toned milk (Saras, 3\% fat) was boiled in an open pan and then $25 \mathrm{~g}$ instant kheer mix was added to it. It was allowed to simmer with constant stirring for 5minutes to obtain the desired consistency. Teng sugar was added in reconstituted kheer, and then cardamom powder was added in small quantity.

\section{Sensory Analysis}

A 15 member semi trained panel was selected through triangle test ${ }^{16}$ to carry out the sensory analysis. Overall acceptability of cooked instant kheer mix was assessed using nine point hedonic test. In this test, the panelists were asked to measure the degree of pleasurable and unpleasurable experience of food products on a nine point scale from "like extremely" to "dislike extremely". The former carried a score of 9 while latter was scored as 1 . Organoleptic characteristics of kheer, prepared by the optimized instant kheer mix were assessed using 5 point composite rating scale. In this test, the panelists were asked to measure the specific characteristics (appearance, color, flavor, consistency and after taste) of a product which were rated separately. Each of these attributes was rated on 5 point scale with 5 considered as "excellent" and 1 considered as "poor".

\section{Experimental plan}

The process optimization of best selected variant of instant kheer mix was conducted. RSM that explores the relationship of several process variables with response variables to get an optimum solution was employed in this study. RSM is a collection of statistical and mathematical techniques for developing, improving and optimizing process. ${ }^{17}$ It is a useful model in studying factors that affect the response by varying them simultaneously and also can be used to study the relationship between one or more responses (dependent variable) and factors (independent variables). ${ }^{18}$ For this purpose, a Central Composite Design (CCD) was used to determine the optimal conditions for the critical factors (Table 1). On the basis of one-at-atime preliminary experiments, the critical factors, amount of cowpea, amount of malted wheat flour and soaking time of cowpea were chosen for the optimization procedure. The effects of these critical factors were seen on response variables - protein, crude fiber and overall acceptability. Twenty sets of experiments of the CCD matrix were generated. The responses were to be estimated in the laboratory and entered into the software data sheet. Experiments were performed in random order.

There were 6 experiments at centre point to calculate the repeatability of method. These data were subjected to one way analysis of variance (ANOVA) and regression coefficients $\left(\mathrm{R}^{2}\right)$ to get the optimum response. A good model must be significant and the lack-of-fit must be insignificant. $\mathrm{R}^{2}$ explains the percentage of the variability of the result. The predicted $\mathrm{R}^{2}$ value should be in reasonable agreement with the adjusted $\mathrm{R}^{2} \cdot{ }^{19} \mathrm{R}^{2}$ can be defined as the ratio of explained variation of the total variation which was a measure of the degree of fit. ${ }^{20}$ The coefficient of variation (CV) describes the extent to which the data are dispersed. ${ }^{21}$

\section{Nutritional analysis}

Moisture and ash contents were determined by standard AOAC methods. Protein was estimated by Micro Kjeldahl method using Kel Plus (model no. KESO61, manufactured by Pelican, India). Fat was estimated using the Soxhlet method using Socs Plus (model no. SCX6, manufactured by Pelican, India). ${ }^{22}$ Crude fiber was determined by the acid alkaline digestion method, iron by Wong's method, calcium by titrimetric method and vitamin $\mathrm{C}$ also by titrimetric method. ${ }^{23}$ Energy was calculated using values given in Nutritive Value of Indian Foods. ${ }^{24}$ 
Table I Experimental runs and actual values of factors/ responses used in central composite rotatable design

\begin{tabular}{|c|c|c|c|c|c|c|}
\hline \multirow[b]{2}{*}{$\begin{array}{l}\text { S. } \\
\text { No }\end{array}$} & \multicolumn{3}{|l|}{ Generated } & \multicolumn{3}{|l|}{ Estimated } \\
\hline & Cowpea (g) & $\begin{array}{l}\text { Malted wheat flour } \\
\text { (g) }\end{array}$ & $\begin{array}{l}\text { Soaking time } \\
\text { (hours) }\end{array}$ & Protein $(g)$ & $\begin{array}{l}\text { Crude fiber } \\
\text { (g) }\end{array}$ & Overall acceptability \\
\hline I & 11.00 & 6.00 & 3.32 & 10.15 & 1.01 & 8.46 \\
\hline 2 & 12.00 & 5.00 & 4.00 & 10.28 & 0.66 & 8.26 \\
\hline 3 & 11.00 & 6.00 & 5.00 & 10.15 & 0.17 & 8.20 \\
\hline 4 & 11.00 & 6.00 & 5.00 & 10.15 & 0.84 & 7.80 \\
\hline 5 & 11.00 & 6.00 & 5.00 & 10.15 & 0.34 & 7.93 \\
\hline 6 & 12.00 & 7.00 & 4.00 & $|0.5|$ & 0.09 & 8.00 \\
\hline 7 & 10.00 & 7.00 & 6.00 & 10.03 & 0.31 & 7.93 \\
\hline 8 & 11.00 & 6.00 & 5.00 & 10.15 & 0.78 & 8.13 \\
\hline 9 & 10.00 & 7.00 & 4.00 & 10.03 & 0.15 & 8.06 \\
\hline 10 & 12.68 & 6.00 & 5.00 & 10.52 & 0.55 & 7.93 \\
\hline II & 12.00 & 5.00 & 6.00 & 10.28 & 0.59 & 7.73 \\
\hline 12 & 11.00 & 6.00 & 5.00 & 10.15 & 0.58 & 8.13 \\
\hline 13 & 11.00 & 6.00 & 5.00 & 10.15 & 0.35 & 8.26 \\
\hline 14 & 11.00 & 6.00 & 6.68 & 10.15 & 0.45 & 7.93 \\
\hline 15 & 12.00 & 7.00 & 6.00 & $|0.5|$ & 0.09 & 8.06 \\
\hline 16 & 10.00 & 5.00 & 6.00 & 9.80 & 0.19 & 8.06 \\
\hline 17 & 11.00 & 4.32 & 5.00 & 9.95 & 0.27 & 8.06 \\
\hline 18 & 11.00 & 7.68 & 5.00 & 10.35 & 0.15 & 8.06 \\
\hline 19 & 9.32 & 6.00 & 5.00 & 9.17 & 0.64 & 8.06 \\
\hline 20 & 10.00 & 5.00 & 4.00 & 9.80 & 0.61 & 8.00 \\
\hline
\end{tabular}

\section{Data analysis}

The experiments were performed and responses were fitted in the design. After each individual experiment, responses were analyzed to assess the effect of independent variables on them. Numerical optimization technique of the Design-Expert software (7.0) was used for simultaneous optimization of the multiple responses. The desired goals for each factor and responses were chosen (Table 2). Responses obtained after each trial were analyzed to visualize the interactive effect of various parameters on protein, crude fiber, and hedonic test scores (overall acceptability) of kheer mix.

Table 2 Levels of responses fixed for optimization of instant kheer mix

\begin{tabular}{|c|c|c|c|c|c|c|}
\hline Factors/ responses & Goal & Lower limit & Upper limit & Lower weight & Upper weight & Importance \\
\hline Cowpea (g) & In range & 10.00 & 12.00 & 1.00 & 1.00 & 3.00 \\
\hline Malted wheat flour (g) & In range & 5.00 & 7.00 & 1.00 & 1.00 & 3.00 \\
\hline Soaking time (hours) & In range & 4.00 & 6.00 & 1.00 & 1.00 & 3.00 \\
\hline Protein (g) & Maximize & 9.75 & 12.00 & 1.00 & 1.00 & 3.00 \\
\hline Fiber $(g)$ & Maximize & 0.75 & 1.00 & 1.00 & 1.00 & 3.00 \\
\hline Overall acceptability & Maximize & 8.00 & 8.50 & 1.00 & 1.00 & 3.00 \\
\hline
\end{tabular}




\section{Results and discussion}

\section{Sensory analysis}

Overall acceptability of instant kheer mix, with its standard recipe and the other four variants was evaluated and assessed using nine point hedonic test. The standard recipe obtained the highest mean score of 8.86. Variant I was the most acceptable recipe (among all variants) containing $10 \mathrm{~g}$ cowpea with 3hours of soaking time and $5 \mathrm{~g}$ malted wheat flour. Variant IV obtained the lowest mean score, prepared from $5 \mathrm{~g}$ cowpea with 12 hours soaking time and $10 \mathrm{~g}$ malted wheat flour. Variant I had a mean hedonic test score of 8.40. Soukkary conducted a study on evaluation of pumpkin seed products for bread fortification in which pumpkin seed products (raw, roasted, autoclaved, germinated, fermented, pumpkin protein concentrate and pumpkin protein isolate) were incorporated into wheat flour to produce blends with protein levels of 15, 17, 19 and $21 \%$. Results indicated that the protein level beyond a certain point resulted in unacceptable bread quality; therefore, there was an upper limit of protein supplementation. Pumpkin protein isolate, fermented pumpkin meal and pumpkin protein concentrate produced the best overall acceptability. ${ }^{25}$

\section{Optimization of parameters for ANOVA}

Fit summary statistics was used to choose a suitable model for a response comparing the models based on p-values. A model is considered significant, if the $\mathrm{p}$ value is less than 0.05 or at least less than 0.1. ANOVA is an important tool for the evaluation of significance and goodness of fit of regression model and significance of individual model coefficients. ${ }^{26}$ The results of ANOVA for the effect of process variables on protein content indicated that, the probability ( $p$ value) was less than $F$ value $(p<0.05)$ for the model (Table 3 ). Thus, the model had a significant effect on the response, protein. Lack of fit is a measure of fitness of the model. Thus the overall result indicated that the model for the responses was significant. Results of effect of process variables on crude fiber indicated that, the $p$ value was more than 0.05 for the model (Table 4). Thus, the model had a non-significant effect on the response, fiber. Lack of fit was non-significant, indicating that model fit the data well. The overall results indicated that the model (Table 5) for the responses was non-significant. The results for the effect of process variables on overall acceptability indicated that, there was no $\mathrm{p}$ value or $\mathrm{F}$ value for the model. Thus, the terms in the model had neither a significant effect nor a non-significant effect on the response.

Table 3 ANOVA for effect of process variables on protein of instant kheer mix

\begin{tabular}{|c|c|c|c|c|c|}
\hline Source & Sum of squares & Degrees of freedom & Mean square & F value & $P$ value Prob $>5$ \\
\hline Model & 0.98 & 9 & 0.11 & 1066.34 & $<0.0001$ \\
\hline A cowpea & 0.79 & I & 0.79 & 7754.91 & $<0.0001$ \\
\hline B malted wheat flour & 0.19 & 1 & 0.19 & 1826.04 & $<0.0001$ \\
\hline C soaking & 0.00 & I & 0.00 & 0.00 & 1.0000 \\
\hline$A B$ & 0.00 & I & 0.00 & 0.00 & 1.0000 \\
\hline AC & 0.00 & 1 & 0.00 & 0.00 & 1.0000 \\
\hline BC & 0.00 & I & 0.00 & 0.00 & 1.0000 \\
\hline$A^{2}$ & $1.093 \mathrm{E}-003$ & I & $1.093 \mathrm{E}-003$ & 10.74 & 0.0083 \\
\hline$B^{2}$ & I.937E-004 & 1 & $1.937 \mathrm{E}-004$ & 1.90 & 0.1977 \\
\hline$C^{2}$ & $1.937 \mathrm{E}-004$ & I & I.937E004 & 1.90 & 0.1977 \\
\hline Residual & $1.017 \mathrm{E}-003$ & 10 & $1.017 \mathrm{E}-004$ & & \\
\hline Lack of fit & $1.017 \mathrm{E}-003$ & 5 & $2.034 \mathrm{E}-004$ & & \\
\hline Pure error & 0.00 & 5 & 0.00 & & \\
\hline Core total & 0.98 & 19 & & & \\
\hline
\end{tabular}


Table 4 ANOVA for effect of process variables on fiber of instant kheer mix

\begin{tabular}{|c|c|c|c|c|c|}
\hline Source & Sum of squares & Degrees of freedom & Mean square & F value & $P$ value $P r o b>5$ \\
\hline Model & 0.77 & 9 & 0.086 & 1.4 & 0.3031 \\
\hline A- cowpea & $2.05 \mathrm{E}-0 \mathrm{I}$ & I & $2.54 \mathrm{E}-05$ & 4.15E-04 & $0.984 I$ \\
\hline B- mated wheat four & 0.19 & I & 0.19 & 3.1 & 0.1086 \\
\hline C- soaking & 0.12 & I & 0.12 & 1.93 & 0.1946 \\
\hline$A B$ & 0.06 & I & 0.067 & 1.09 & 0.3217 \\
\hline AC & $4.5 \mathrm{IE}-03$ & I & 4.5 IE-03 & 0.074 & 0.7919 \\
\hline BC & 0.053 & I & 0.053 & 0.86 & 0.3751 \\
\hline $\mathrm{A} 2$ & 7.03E-04 & I & 7.03E-04 & 0.011 & 0.9168 \\
\hline B2 & 0.3 & I & 0.3 & 4.82 & 0.0529 \\
\hline $\mathrm{C} 2$ & 0.02 & I & 0.024 & 0.39 & $0.546 I$ \\
\hline Residual & 0.61 & 10 & 0.061 & & \\
\hline Lack of fit & 0.26 & 5 & 0.051 & 0.72 & 0.6378 \\
\hline Pure error & 0.36 & 5 & 0.071 & & \\
\hline Core total & 1.38 & 19 & & & \\
\hline
\end{tabular}

Table 5 ANOVA for effect of process variables on overall acceptability of instant kheer mix

\begin{tabular}{lllll}
\hline Source & Sum of squares & Degrees of freedom & Mean square & F value \\
\hline Model & & 0.0 & 0.000 & \\
Residual & & 0.5 & 19.000 & 0.027 \\
Lack of fit & 0.37 & 14 & 0.026 & 0.860 \\
Pure error & 0.15 & 5 & 0.031 & \\
Core total & 0.52 & 19 & & \\
\hline
\end{tabular}

\section{Optimization of parameters for regression coefficients} (R2)

The estimated regression coefficients of the quadratic, regression coefficients of intercepts, linear and cross product terms of model, are obtained by fitting protein, crude fiber and overall acceptability. The data are presented in Table 6 . The fitness and adequacy of the model were judged by the coefficient of determination. A suitable model is the one with the highest order polynomial where the model is significant.
The closer the $\mathrm{R}^{2}$ value to unity, the better the empirical model fits the actual data. The $\mathrm{R}^{2}$ values were 0.9980 and 0.1519 for protein and fiber respectively, suggesting a fair fit of the model. The CV describes the extent to which the data are dispersed. The higher $\mathrm{CV}$ values for protein and fiber indicated that the results were comparatively less precise and reliable. The lower CV value for overall acceptability indicated that the result was precise and reliable. Similar results were observed in a study of Jain et al. ${ }^{27}$ 
Table 6 Regression coefficients of predicted quadratic polynomial models of instant kheer mix.

\begin{tabular}{llll}
\hline Coefficient & Protein & Fiber & Overall acceptability \\
\hline Intercept & 10.150 & 0.520 & 8.050 \\
Linear & & & \\
A & 0.240 & $1.365 \mathrm{E}-003$ & \\
B & 0.120 & -0.120 & \\
C & 0.000 & -0.093 & \\
Quadratic & & & \\
A $^{2}$ & $-8.708 \mathrm{E}-003$ & $-6.986 \mathrm{E}-003$ & \\
$\mathrm{~B}^{2}$ & $3.666 \mathrm{E}-003$ & -0.140 & \\
C $^{2}$ & $3.666 \mathrm{E}-003$ & $0.04 \mathrm{I}$ & \\
Cross product & & & \\
AB & 0.000 & $-0.09 \mathrm{I}$ & \\
AC & 0.000 & 0.024 & \\
BC & 0.000 & 0.081 & 0.000 \\
$R^{2}$ & 0.999 & 0.557 & 0.000 \\
Adjusted $\mathrm{R}^{2}$ & 0.998 & 0.159 & 2.050 \\
CV\% & 0.099 & 56.13 & \\
\hline
\end{tabular}

$\mathrm{R}^{2}$, regression coefficient; $\mathrm{CV}$, coefficient of variation

\section{Effect of process condition for protein}

The observations for protein with different combinations of process parameters are presented in Table 1. Experimentally, the minimum protein $(9.17 \mathrm{~g})$ and maximum protein $(10.52 \mathrm{~g})$ were obtained. The regression equation describing the effect of the process variable on protein on precooked instant kheer mix in terms of actual level of variables is given as:

Protein $=+5.97597+0.43191 *$ Cowpea $+0.072627 *$ Malted Wheat Flour $0.036664 *$ Soaking +0.000000

*Cowpea *Malted Wheat Flour+0.000000 *Cowpea *Soaking +0.000000 *Malted Wheat Flour *Soaking-.70796 E-003*Cowpea 2+3.66641 E003*Malted Wheat Flour $^{2}+3.66641$ E-003 * Soaking ${ }^{2}$

The interactive effect of process variables cowpea and malted wheat flour on the protein content (Figure 1) depicted that the minimum protein content $(9.91009 \mathrm{~g})$ was obtained at $10 \mathrm{~g}$ cowpea and $5 \mathrm{~g}$ malted wheat flour. The maximum protein content $(10.386 \mathrm{~g})$ was obtained at $12 \mathrm{~g}$ cowpea and $7 \mathrm{~g}$ malted wheat flour. The interactive effect of process variables cowpea and soaking time on the protein content is presented in Figure 2. It depicted that the minimum protein content $(9.86976 \mathrm{~g})$ was obtained at $10 \mathrm{~g}$ cowpea and 4hours soaking time. The maximum protein content $(10.1927 \mathrm{~g})$ was obtained at $12 \mathrm{~g}$ cowpea and 6hours soaking time. The interactive effect of process variables malted wheat flour and soaking time on the protein content (Figure 3) represented that the minimum protein content (10.3076g) was obtained at $5 \mathrm{~g}$ malted wheat flour and 4 hours soaking time. The maximum protein content $(10.4655 \mathrm{~g})$ was obtained at $7 \mathrm{~g}$ malted wheat flour and 6hours soaking time.

\section{Effect of process condition for fiber}

The observations for fiber with different combinations of process parameters are presented in Table 1. Experimentally, the minimum fiber $(0.09 \mathrm{~g})$ was obtained at $12 \mathrm{~g}$ cowpea, 4hours soaking time and
$7 \mathrm{~g}$ of malted wheat flour. The maximum fiber $(1.01 \mathrm{~g})$ was obtained at $11 \mathrm{~g}$ cowpea, 3.32 hours soaking time and $6 \mathrm{~g}$ malted wheat flour. The regression equation describing the effect of the process variable on fiber in precooked instant kheer mix in terms of actual level of variables is given as-

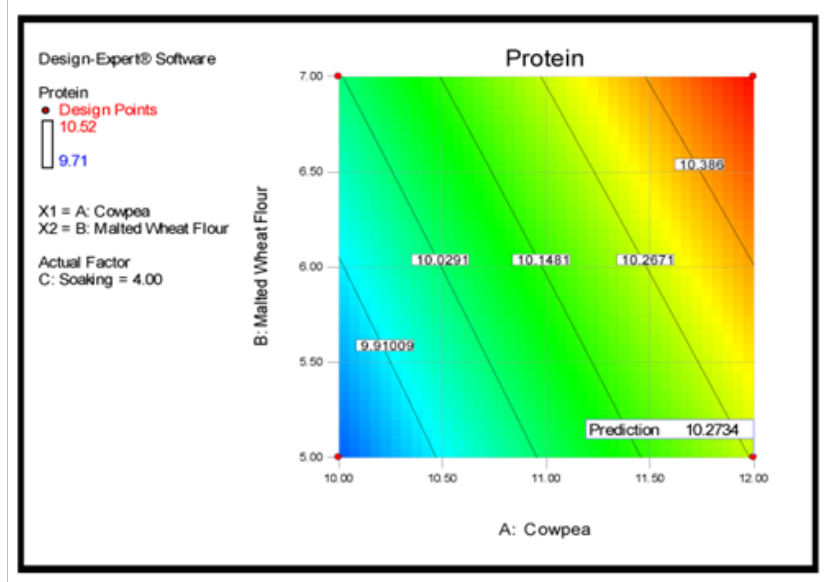

Figure I Interactive effect of cowpea and malted wheat flour on protein content of instant kheer mix.

Fiber $=-5.58287+0.58382 *$ Cowpea $+2.19673 *$ Malted Wheat Flour-1.24931*Soaking $0.091250 *$ Cowpea *Malted Wheat Flour $+0.023750 *$ *owpea*Soaking $+0.081250 *$ Malted Wheat Flour*Soaking-6.98643E-003*Cowpea ${ }^{2}-0.14310$ Malted Wheat Flour $^{2}+0.040743 *$ Soaking $^{2}$

The interactive effect of process variables cowpea and malted wheat flour on the fiber content (Figure 4) indicated that the maximum fiber content $(0.670742 \mathrm{~g})$ was obtained at $10 \mathrm{~g}$ cowpea and $5 \mathrm{~g}$ malted wheat flour and the minimum fiber content $(0.283378 \mathrm{~g})$ was obtained at $12 \mathrm{~g}$ cowpea and $7 \mathrm{~g}$ malted wheat flour. The interactive effect of process variables malted wheat flour and soaking time on the fiber 
content is presented in Figure 5. It depicts that the maximum fiber content $(0.665786 \mathrm{~g})$ was obtained at $5 \mathrm{~g}$ malted wheat flour and 4 hours soaking time. The minimum fiber content $(0.258601 \mathrm{~g})$ was obtained at $7 \mathrm{~g}$ malted wheat flour and 6hours soaking time. The interactive effect of process variables cowpea and soaking time on the fiber content (Figure 6) illustrated that the maximum fiber content $(0.679332 \mathrm{~g})$ was obtained at $11.2 \mathrm{~g}$ cowpea and 4hours soaking time. The minimum fiber content $(0.326705 \mathrm{~g})$ was obtained at $10.5 \mathrm{~g}$ cowpea and 5.4 hours soaking time.

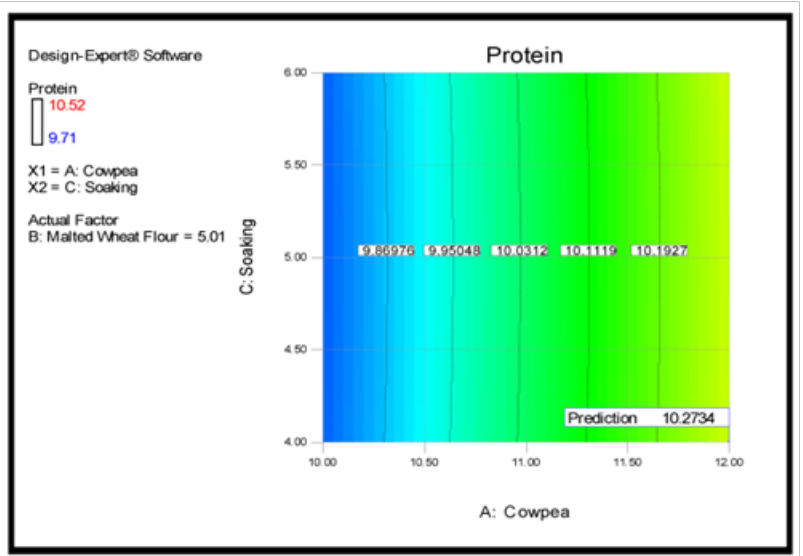

Figure 2 Interactive effect of cowpea and soaking time on protein content of instant kheer mix.

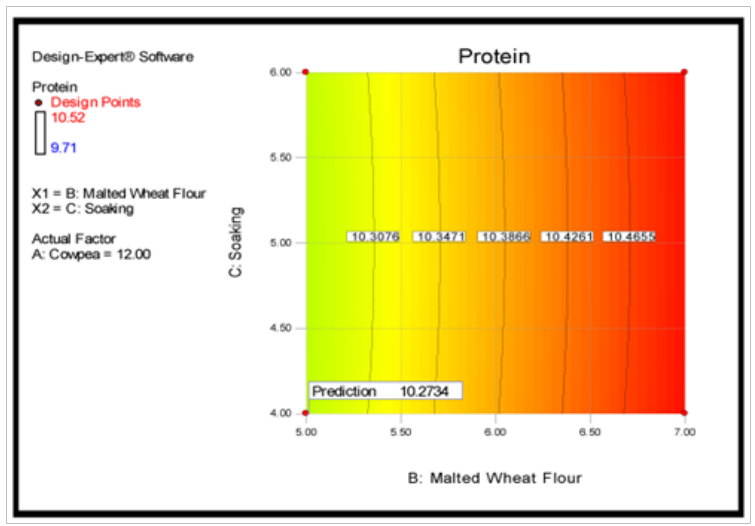

Figure 3 Interactive effect of malted wheat flour and soaking time on protein content of instant kheer mix.

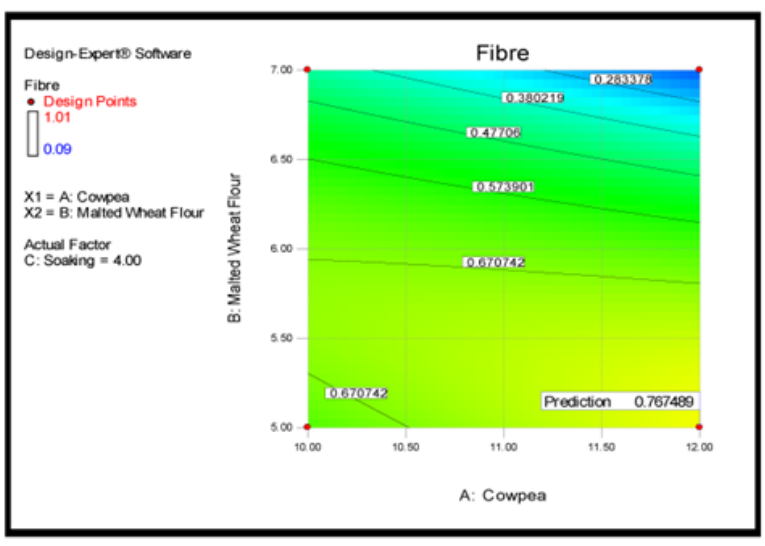

Figure 4 Interactive effect of cowpea and malted wheat flour on fiber content of instant kheer mix.

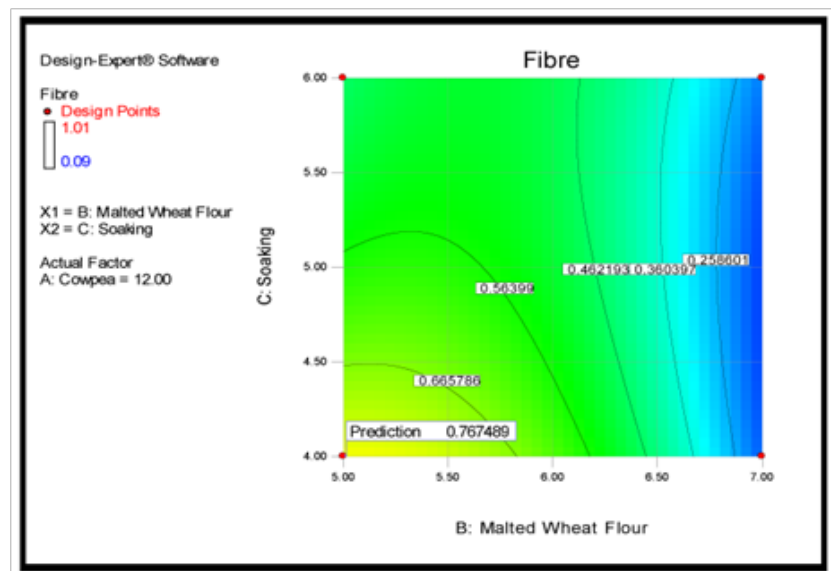

Figure 5 Interactive effect of malted wheat flour and soaking time on fiber content of instant kheer mix.

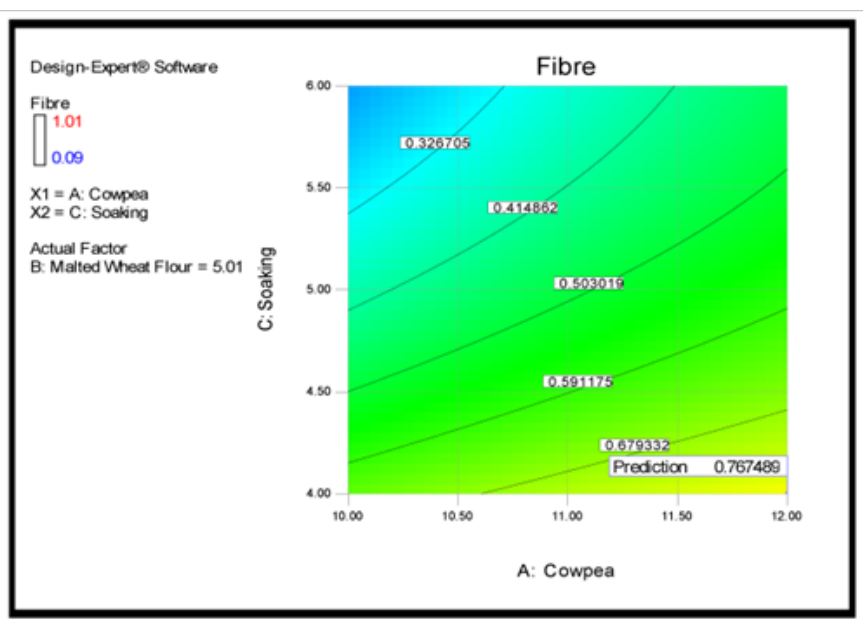

Figure 6 Interactive effect of cowpea and soaking time on fiber content of instant kheer mix.

\section{Effect of process condition for overall acceptability (hedonic test score)}

The observations for overall acceptability with different combinations of process parameters are presented in Table 1. Experimentally, the minimum overall acceptability (7.93) was obtained at $11 \mathrm{~g}$ cowpea, 5 hour soaking time and $6 \mathrm{~g}$ malted wheat flour, while the maximum overall acceptability (8.46) was obtained at $11 \mathrm{~g}$ cowpea, 3.32 hour soaking time and $6 \mathrm{~g}$ malted wheat flour. Increasing the amount of cowpea had a positive effect on overall acceptability score. The regression equation describing the effect of the process variable on overall acceptability of precooked instant kheer mix in terms of actual level of variables is given as Overall acceptability $=+8.05250$

The overall acceptability score of kheer and kheer like dairy desserts was affected by the rice grain particle, milk solids and sugar content. $^{3}$

\section{Optimization of process parameters}

Numerical optimization was carried out for the process parameters for obtaining the optimum product for high protein. To perform this operation, Design-Expert software (Design Expert, 7.0) was used for simultaneous optimization of the multiple responses. The 
desired goals for each factor and response were chosen (Table 2). The software generated 13 optimum solutions of process variables with the predicted values of responses (Table 7). Solution 3, having the maximum desirability value, along with the maximum protein content, maximum crude fiber content and maximum overall acceptability was selected as optimum for instant kheer mix. A study was conducted on development of corn and flaxseed snacks with high fiber content using RSM. In this study, the production of a high-fiber content snack food from a mixture of corn and flaxseed flours was optimized by RSM. The independent variables considered in this study were: feed moisture, process temperature and flaxseed flour addition, as they were found to significantly impact the resultant product. These variables were studied according to a rotatable composite design matrix (-1.68, -1, 0,1 , and 1.68). Response variable was the expansion ratio since it has been highly correlated with acceptability. The optimum corn flaxseed snack obtained presented a sevenfold increase in dietary fiber, almost $100 \%$ increase in protein content compared to the pure corn snack, and yielded an acceptability score of 6.93. This acceptability score was similar to those observed for corn snack brands in the market, indicating the potential commercial use of this new product, which can help to increase the daily consumption of dietary fiber. ${ }^{28}$

Table 7 Solutions for optimum conditions of instant kheer mix

\begin{tabular}{llllllll}
\hline $\begin{array}{l}\text { S. } \\
\text { No }\end{array}$ & $\begin{array}{l}\text { Cowpea } \\
(\mathbf{g})\end{array}$ & $\begin{array}{l}\text { Malted wheat } \\
\text { flour }(\mathbf{g})\end{array}$ & $\begin{array}{l}\text { Soaking time } \\
\text { (hours) }\end{array}$ & $\begin{array}{l}\text { Protein } \\
(\mathbf{g})\end{array}$ & Fiber $(\mathbf{g})$ & $\begin{array}{l}\text { Overall } \\
\text { acceptability }\end{array}$ & Desirability \\
\hline 1 & 12.00 & 5.00 & 4.00 & 10.2718 & 0.767582 & 8.0525 & 0.120 \\
2 & 12.00 & 5.01 & 4.00 & 10.0726 & 0.767544 & 8.0525 & 0.120 \\
3 & 12.00 & 5.01 & 4.00 & 10.2734 & 0.767489 & 8.0525 & 0.120 \\
4 & 12.00 & 5.04 & 4.00 & 10.2766 & 0.767111 & 8.0525 & 0.119 \\
5 & 11.99 & 5.00 & 4.00 & 10.2690 & 0.766899 & 8.0525 & 0.118 \\
6 & 12.00 & 5.09 & 4.00 & 10.2813 & 0.766128 & 8.0525 & 0.117 \\
7 & 12.00 & 5.11 & 4.00 & 10.2834 & 0.765512 & 8.0525 & 0.116 \\
8 & 11.97 & 5.00 & 4.00 & 10.2656 & 0.765936 & 8.0525 & 0.115 \\
9 & 12.00 & 5.12 & 4.00 & 10.2845 & 0.765154 & 8.0525 & 0.115 \\
10 & 12.00 & 5.00 & 4.01 & 10.2717 & 0.764173 & 8.0525 & 0.114 \\
11 & 12.00 & 5.04 & 4.01 & 10.2755 & 0.764096 & 8.0525 & 0.111 \\
12 & 11.93 & 5.06 & 4.00 & 10.2639 & 0.763444 & 8.0525 & 0.109 \\
13 & 11.83 & 5.06 & 4.00 & 10.2394 & 0.757937 & 8.0525 & 0.090 \\
\hline
\end{tabular}

\section{Sensory analysis for optimum product}

The sensory attributes of optimized instant kheer mix were evaluated using 5 point composite rating scale. Mean score for all the attributes were above 4 . The mean scores for appearance, color, taste, consistency, after taste of optimum recipe were 4.53, 4.53, 4.46, 4.73 and 4.66 respectively. This recipe had $12 \mathrm{~g}$ cowpea with 4 hours soaking time and 5.01g malted wheat flour. A study regarding physical and sensory characteristics of sugar cookies containing mixtures of wheat, fonio and cowpea flours was conducted by a group of researchers. They reported that the $100 \%$ wheat and the $50 \%$ wheat $/ 50 \%$ cowpea cookies had the lightest color and the $25 \%$ wheat $/ 75 \%$ fonio the darkest. Sensory panel assessments of appearance, color and texture were not affected by component flours. Cookies containing 100\% wheat or $50 \%$ wheat $/ 50 \%$ fonio received the highest hedonic ratings for flavor (7.1 and 6.7, respectively) and overall acceptability (6.9 and 6.5 , respectively). All other formulations were unacceptable. ${ }^{29}$ Optimization of instant dalia dessert premix production by using response surface methodology were carried out and the formulation had $17.82 \%$ milk solids and $2.87 \%$ wheat solids. This formulation was found to be most appropriate for manufacture of instant dalia premix with predicted sensory scores (maximum 100) of 85.35, 41.98 and 67.27 for mouth feel, consistency and flavor, respectively. ${ }^{5}$

\section{Nutritional analysis}

The food product had moisture content of $2.98 \mathrm{~g} / 100 \mathrm{~g}$ and ash content of $3.46 \mathrm{~g} / 100 \mathrm{~g}$. Protein content was $10.15 \mathrm{~g} / 100 \mathrm{~g}$, Fat content was $3.0 \mathrm{~g} / 100 \mathrm{~g}$, Crude fiber content was $1.01 \mathrm{~g} / 100 \mathrm{~g}$, Iron content was $0.79 \mathrm{mg} / 100 \mathrm{~g}$, calcium content was $174.14 \mathrm{mg} / 100 \mathrm{~g}$ and vitamin $\mathrm{C}$ content was $6.60 \mathrm{~g} / 100 \mathrm{~g}$ in the optimum recipe. The energy (calculated) was $249.95 \mathrm{kcal}$. In a study moin was prepared from $100 \%$ cowpea flour. Sample A (control) had a crude protein content of $21.89 \%$. The crude protein decreased to $15.40 \%$ as the level of maize substitution increased from 0 to $70 \%$ whereas the carbohydrate content increased from 15.87 to $34.72 \%$ as the level of maize substitution increased from 0 to $70 \%{ }^{30} \mathrm{Jha}$ et al., ${ }^{2}$ reported a composition of $6.38 \%$ fat, 5.44 $\%$ protein, $34.01 \%$ moisture, $38.23 \%$ total solids and $1.23 \%$ ash for ready-to-eat pearl millet based dairy dessert. Mcwatters et al., ${ }^{29}$ conducted a study on baking performance and consumer acceptability of raw and extruded cowpea flour bread. They concluded that the cowpea flour breads contained more protein (13.9-15.4\%) than the $100 \%$ wheat ( $4.1 \%$ fat, $12.5 \%$ protein). In a study on the nutritional and sensory profiles of sweet potato based infant weaning food development, sweet potato, cowpea and peanut flour were used. The results of the nutritional properties revealed a significant increase of crude protein ranging from $18.9 \pm 3.2-38.5 \pm 8.4 \%$ (dry matter based), ash content (2.8 $\pm 0.8-3.361 .8 \%)$, fat $(2.4 \pm 0.3-1.8 \pm 3.2 \%)$, crude fiber 
$(2.8 \pm 0.7-4.8 \pm 0.8 \%)$ and carbohydrate $(42.3 \pm 8.0-62.5 \pm 3.9 \%)$. The addition of cowpea and peanut flour increased the protein content of weaning food. ${ }^{31}$ These results were similar to the present investigation.

\section{Conclusion}

The optimized levels of amount of cowpea, soaking time of cowpea and amount of malted wheat flour for the manufacture of the instant kheer mix were predicted based on protein, crude fiber and overall acceptability score using RSM. Out of 13 suggested formulations, formulation 3 had superior overall acceptability rating (8.0525) and highest desirability index $(0.120)$ compared to all other formulations. Hence, the formulation with amount of cowpea $(12 \mathrm{~g})$, soaking time of cowpea (4hours) and malted wheat flour $(5.01 \mathrm{~g})$ was considered most suitable for manufacturing instant kheer dry mix, which could be then reconstituted into kheer. The predicted scores of $10.2734 \mathrm{~g}$ for protein, $0.767489 \mathrm{~g}$ for crude fiber, and 8.0525 for overall acceptability score were obtained. Developing such value-added products from staple cereals could bring variety for consumers offering them nutritional benefits. Optimum recipe had $10.15 \mathrm{~g}$ protein. Instant kheer mix had good sensory characteristics. This food product is convenient to use, health promoting and cost effective; hence, it can be used in various food based intervention programmes.

\section{Acknowledgements}

None.

\section{Conflict of interest}

The author declares no conflict of interest.

\section{References}

1. Kadam BR, Lembhe AF, Zanjad PN. Formulation of kheer readymix based on sensory attributes. Tamil Nadu J Veterinary and Animal Sciences. 2011;7(2):88-93.

2. Jha A, Tripathi AD, Alam T, et al. Process optimization for manufacture of pearl millet-based dairy dessert by using response surface methodology (RSM). J Food Sci Technol. 2013;50(2):367-373.

3. Jha A, Patel AA, Singh RRB. Physico-chemical properties of instant kheer mix. Lait. 2002;82(4):501-513.

4. Jha SN, Verma BB. Optimization of process parameters for absorption of milk by makhana. J Food Sci Technol. 2000;37(5):488-492.

5. Jha A, Shalini BN, Patel AA, et al. Optimization of instant dalia dessert premix production by using response surface methodology. J Food Sci Technol. 2013;10.1007/s13197-013-1052-5.

6. Siddhuraju P, Becker K. The antioxidant and free radical scavenging activities of processed cowpea (Vigna unguiculata (L.) Walp) seed extracts. Food Chemistry. 2007;101(1):10-19.

7. Anlin LI, Shuangi X, Zhenquiong H. Functional properties analysis of protein isolated from cowpea seeds. Journal of Anhui Agricultural Sciences. 2008;19(2):741-742.

8. Okarter N, Liu RH. Health benefits of whole grain phytochemical. Crit Rev Food Sci Nutr. 2010;50(3):193-208.

9. Pelembe LAM, Erasmus C, Taylor JRN. Development of a proteinrich composite sorghum-cowpea instant porridge by extrusion cooking process. LWT - Food Science and Technology. 2002;35(2):120-127.

10. Sadana B, Chabra C. Development and sensory evaluation of low cost weaning food formulations. J Hum Ecol. 2004;16(2):133-136.

11. Mridula D, Goyal RK, Manikantan MR. Effect of roasting on texture, color and acceptability of Pearl Millet (Pennisetum glaucum) for making Sattu. International Journal of Agricultural Research. 2008;3(1):61-68.
12. Floros J. Food science: Feeding the world. J Food Sci Technol. 2008;62:11.

13. Wadikar DD, Nanjappa C, Premavelli KS, et al. Development of ginger based ready-to-eat appetizers by response surface methodology. Appetite. 2010;55(1):76-83.

14. Chakraborty SK, Kumbhar BK, Chakraborty S, et al. Influence of processing parameters on textural characteristics and overall acceptability of millet enriched biscuit using response surface methodology. J Food Sci Technol. 2011;48(2):167-174.

15. Das L, Raychaudhuri U, Chakraborty R. Effect of baking conditions on the physical properties of herbal bread using RSM. International Journal of Food, Agriculture and Veterinary Sciences. 2012;2(2):106-114.

16. Srilakshmi B. Food Science. New Delhi: New Age International Publishers Pvt Ltd; 1999.

17. Myers RH, Montgomery DC, Anderson-Cook CM. Response surface methodology: Process and product optimization using designed experiments. 3rd ed. New York: Wiley; 2002.

18. Yaakob H, Ahmed RN, Daud KS, et al. Optimization of ingredient and processing levels for the production of coconut yoghurt using response surface methodology. Food Sci Biotechnol. 2012;21(4):933-940.

19. Bunkar DS, Jha A, Mahajan A. Optimization of the formulation and technology of pearl millet based 'ready-to-reconstitute' kheer mix powder. J Food Sci Technol. 2014;51(10):2404-2414.

20. Chan SW, Lee CY, Yap CF, et al. Optimization of extraction conditions for phenolic compounds from limau purut (Citrus hystrix) peels. International Food Research Journal. 2009;16:203-213.

21. Liyana-Pathirana C, Shahidi F. Optimization of extraction of phenolic compounds from wheat using response surface methodology. Food Chemistry. 2005;93(1):47-56.

22. AOAC. Official Methods of Analysis. 17th ed. Maryland: Association of Official Agricultural Chemists; 2002.

23. NIN. A Manual of Laboratory Techniques. Hyderabad, India: National Institute of Nutrition, Indian Council of Medical Research; 2003.

24. Gopalan C, Rama Sastri BV, Balasubramanian SC. Nutritive Value of Indian Foods. National Institute of Nutrition Hyderabad, India: , Indian Council of Medical Research; 2004.

25. Soukkary FA. Effect of pumpkin seed products for bread fortification. Plant Foods Hum Nutr. 2001;56(4):365-384.

26. Fentie M, Belete A, Gebre-Mariam T. Formulation and optimization of controlled release floating microspheres of Furosemide from ethylcellulose and hydroxypropyl methylcellulose polymer blends. IJPSR. 2014;5(1):70-82.

27. Jain M, Singh C, Gupta K, et al. Optimization of functional food ingredients and their processing levels for preparation of vermicelli using RSM. IJESRT. 2014;3(6):8-20.

28. Trevisan AJ, Areas JA. Development of corn and flaxseed snacks with high-fiber content using response surface methodology (RSM). Int $J$ Food Sci Nutr. 2012;63(3):362-367.

29. Mcwatters KH, Ouedraogo JB, Resurreccion VA, et al. Physical and sensory characteristics of sugar cookies containing mixtures of wheat, fonio (Digitaria exilis) and cowpea (Vigna unguiculata) flours. Int $J$ Food Sci. 2003;38(4):403-410.

30. Akusu OM, Kiin-Kabari DB. Protein quality and sensory evaluation of moin-moin prepared from cowpea/maize flour blends. African Journal of Food Science. 2012;6(3):47-51.

31. Adenuga W. Nutrition and sensory profiles of sweet potato based infant weaning food fortified with cowpea and peanut. Journal of Food Technology. 2010;8(5):223-228. 